San Jose State University

SJSU ScholarWorks

Master's Theses

Master's Theses and Graduate Research

Spring 2012

\title{
Plasmablast Frequency and Trafficking Receptor Expression are Altered in Pediatric Ulcerative Colitis
}

Nicole Jeanne Tarlton

San Jose State University

Follow this and additional works at: https://scholarworks.sjsu.edu/etd_theses

\section{Recommended Citation}

Tarlton, Nicole Jeanne, "Plasmablast Frequency and Trafficking Receptor Expression are Altered in Pediatric Ulcerative Colitis" (2012). Master's Theses. 4174.

DOI: https://doi.org/10.31979/etd.v8vm-merw

https://scholarworks.sjsu.edu/etd_theses/4174

This Thesis is brought to you for free and open access by the Master's Theses and Graduate Research at SJSU ScholarWorks. It has been accepted for inclusion in Master's Theses by an authorized administrator of SJSU ScholarWorks. For more information, please contact scholarworks@sjsu.edu. 
PLASMABLAST FREQUENCY AND TRAFFICKING RECEPTOR EXPRESSION ARE ALTERED IN PEDIATRIC ULCERATIVE COLITIS

\author{
A Thesis \\ Presented to \\ The Faculty of the Department of Biological Sciences \\ San José State University \\ In Partial Fulfillment \\ of the Requirements for the Degree \\ Master of Science \\ by
}

Nicole J. Tarlton

May 2012 
(C) 2012

Nicole J. Tarlton

ALL RIGHTS RESERVED 
The Designated Thesis Committee Approves the Thesis Titled

PLASMABLAST FREQUENCY AND TRAFFICKING RECEPTOR EXPRESSION ARE ALTERED IN PEDIATRIC ULCERATIVE COLITIS

by

Nicole J. Tarlton

APPROVED FOR THE DEPARTMENT OF BIOLOGICAL SCIENCES

SAN JOSÉ STATE UNIVERSITY

May 2012

Dr. Tzvia Abramson, Committee Chair

Dr. William J. Murray

Dr. Eugene C. Butcher
Department of Biological Sciences

Department of Biological Sciences

Department of Pathology, Stanford 


\section{ABSTRACT \\ PLASMABLAST FREQUENCY AND TRAFFICKING RECEPTOR EXPRESSION ARE ALTERED IN PEDIATRIC ULCERATIVE COLITIS \\ by Nicole J. Tarlton}

The incidence of pediatric ulcerative colitis (UC), a chronic autoinflammatory disease of the colon, is on the rise. Although an increased infiltration of B cells from the peripheral blood into the colon occurs in UC, B cell trafficking is understudied. We hypothesized that the frequency of circulating plasmablasts (PBs) and their trafficking receptor (TR) expression may be indicative of the location and degree of pathology in pediatric UC. We conducted multicolor flow cytometry analyses of circulating $\operatorname{IgA}^{+/-}$ PBs and $\operatorname{IgA}^{+}$memory B cells (MBCs) in pediatric UC patients with remission, mild, moderate, and severe disease $(n=12)$ and healthy pediatric $(n=2)$ and adult donors $(n=11)$. Compared to healthy donors the average frequency of circulating PBs increased 30-fold during severe UC activity and positively correlated with Pediatric Ulcerative Colitis Activity Index score, C-reactive protein level, and erythrocyte sedimentation rate. A greater percent of PBs in severe patients expressed the gut-homing receptors $\alpha 4 \beta 7$ and CCR10, and the inflammatory homing molecule P-selectin ligand (P-sel lig). The percent of $\operatorname{IgA}^{+}$MBCs expressing $\alpha 4 \beta 7$, however, was reduced. Furthermore, expression of the small intestine TR CCR9 decreased on $\alpha 4 \beta 7^{\text {high }}$ PBs and on $\alpha 4 \beta 7^{\text {high }} / \mathrm{CCR} 10^{\text {high }} \mathrm{PBs}$ and MBCs in these patients, consistent with preferential cell targeting to the colon. In conclusion, peripheral blood PBs with a colon-homing phenotype were elevated in children with severe UC. Screening this B cell subset may provide a complementary approach in monitoring disease activity or therapeutic efficacy in pediatric UC. 


\section{ACKNOWLEDGEMENTS}

This work is the result of collaborative efforts between San José State University, Kaiser Permanente in Santa Clara, and Stanford University. First I would like to thank Dr. Anthony Wong and Dr. Oren Abramson, the pediatric gastroenterologists at Kaiser Permanente, for recruiting patients for this study. In addition, many thanks are due to the patients and healthy donors who participated in this study, without whose contribution this work would not have been possible. Next I would like to thank Caroline Green for getting this project started at San José State University, and for the extensive training she provided me. Many thanks are due to Nicole Lazarus and Lusijah Rott from Stanford University for protocol design, for training and support in the lab - especially with the LSRII flow cytometer - and for critical editing of this manuscript. Also, thank you to Dr. Kenneth Youngman for critically editing this manuscript, and thank you to Dr. Martina Bremer for assistance with statistical analyses.

Finally, many thanks are due to my outstanding thesis committee advisors, Dr. Tzvia Abramson, Dr. Eugene Butcher, and Dr. William Murray. Thank you to Dr. Abramson for being my major advisor and mentor for my MS degree and thesis. Thank you to Dr. Butcher for your support and advice on this project, and for critical editing of the manuscript. Thank you to Dr. Murray for your mentorship, advice, and support throughout my time at San José State University. In addition, I would like to acknowledge our sources of funding for this work, which was supported by funds from CSUPERB, from NIH grants R37 AI047822, U19 AI090019, and RC1 AI087257, and funds from the Gates Foundation. 


\section{TABLE OF CONTENTS}

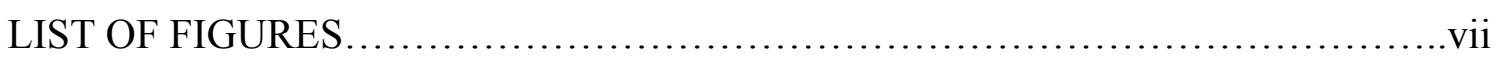

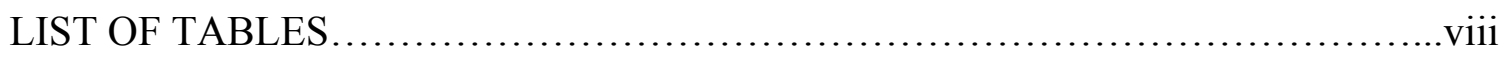

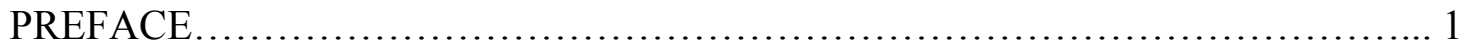

CHAPTER I

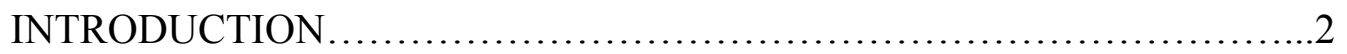

CHAPTER II

PLASMABLAST FREQUENCY AND TRAFFICKING RECEPTOR

EXPRESSION ARE ALTERED IN PEDIATRIC ULCERATIVE

COLITIS.....................................................6

CHAPTER III

CONCLUSION ......................................................... 36

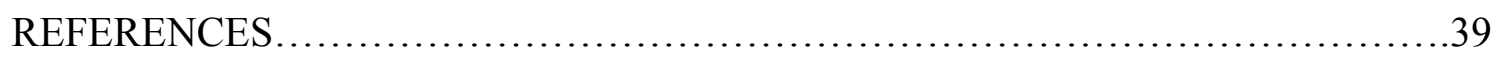




\section{LIST OF FIGURES}

FIGURE 1. $\operatorname{IgA}^{+/-}$plasmablast and $\operatorname{IgA}^{+}$memory B cell flow cytometry gating strategy, and cell percentages in the peripheral blood.............................. 18

FIGURE 2. Correlation between C-reactive protein levels, Pediatric Ulcerative Colitis Activity Index score, and percent of $\operatorname{IgA}^{+}$plasmablasts in the peripheral

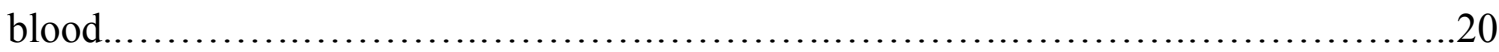

FIGURE 3. Single trafficking receptor analysis on $\operatorname{IgA}^{+/-}$plasmablasts...............21

FIGURE 4. Trafficking receptor analysis on mucosal and non-mucosal $\operatorname{Ig} \mathrm{A}^{+/-}$

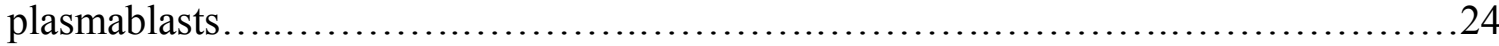

FIGURE 5. Comparison of trafficking receptor co-expression on $\operatorname{Ig} \mathrm{A}^{+}$

plasmablasts and $\operatorname{IgA}^{+}$memory $\mathrm{B}$ cells, and single trafficking receptor expression

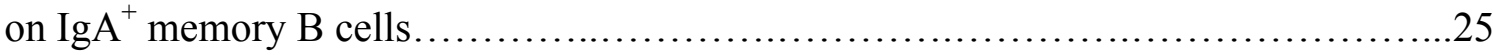

FIGURE 6. CCR 9 expression on $\alpha 4 \beta 7^{\text {high }} / \mathrm{CCR} 10^{\text {high }} \operatorname{Ig} \mathrm{A}^{+/-}$plasmablasts and

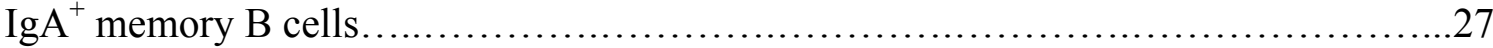




\section{LIST OF TABLES}

Table 1. List of pediatric UC patients and blood sample information..................12 


\section{PREFACE}

This thesis is composed of three chapters. Chapter I provides an overview of the research project, detailing the rationale behind the project design. Chapter II presents the manuscript entitled Plasmablast Frequency and Trafficking Receptor Expression are Altered in Pediatric Ulcerative Colitis in journal format according to the guidelines set by the journal Inflammatory Bowel Diseases, to which this manuscript was accepted for publication. Chapter III summarizes the conclusions of this work, as well as discusses the future directions for this project. 


\section{CHAPTER I}

INTRODUCTION 


\section{Overview of the Research Project}

Inflammatory Bowel Disease (IBD) is a group of chronic autoimmune and inflammatory disorders of the gastrointestinal tract (GI), encompassing Crohn's Disease (CD) and ulcerative colitis (UC). The two diseases are distinguished based on the appearance and location of lesion formation in the GI tract: CD is characterized by discreet penetrating lesions that may be spread all throughout the GI tract, while the lesions in UC are diffuse and superficial, and only occur in the colon. UC was the initial focus of this research because lesion involvement is limited to one organ- the colonand hence changes in the parameters we measured could more easily be attributed to immunopathology in the colon, vs. in CD where the occurrence of immunopathology in one or more organs would have to be accounted for.

While both children and adults may be affected by UC, pediatric patients were the focus of our study for several reasons: 1) pediatric patients with a recent onset of illness (vs. adults that have had the disease for a longer period of time) would demonstrate fewer confounding effects of comorbidities and long-term medication, 2) fatal $\gamma \delta$-T cell and plasmablast lymphomas have been reported in pediatric patients with IBD, and 3) pediatric patients with UC are much understudied in comparison to their adult counterparts.

While the etiology and mechanism of UC is not fully understood, immunologic abnormalities play a role in this disease. An increased recruitment of lymphocytes from the peripheral blood into the colon is one such abnormality, ultimately leading to inflammation and GI tissue damage. The recruitment of circulating lymphocytes, i.e. B 
and $\mathrm{T}$ cells, is tightly controlled by a multi-step process involving trafficking receptors (TRs) expressed on the lymphocyte surface, that act in combination to govern these immune cells' migration to the target organ. Focusing on B cells-a lymphocyte subset highly implicated in autoimmune/autoinflammatory disorders such as UC—we hypothesized that the percent of circulating plasmablasts (an activated B cell population) would be increased during disease activity in pediatric UC and would demonstrate an altered pattern of TR expression indicative of cell homing to the colon.

We used multicolor flow cytometry analysis to examine the combinatorial expression of TRs on the B cell surface. Our approach is novel in that we examine 10+ surface molecules simultaneously using only one tube of cells. In addition, our protocol was designed to require only one tube of peripheral blood from the pediatric donors, making participation in this study minimally invasive to the patients.

Our research was designed to address the following issues: 1) the methods to monitor the progression of disease and the immune response to therapeutics are typically invasive, and 2) there remains a need to more effectively follow changes in the immune system — which may occur as a natural progression of the disease itself or may result from disease treatment — that may lead to severe side effects, such as lymphomas. We have found that pediatric UC patients with severe disease have an increased frequency of plasmablasts in the peripheral blood that express $\alpha 4 \beta 7$, CCR10, and P-selectin ligandTRs which, in combination, are indicative of cell homing to the colon. Screening this B cell subset may provide a complementary approach in monitoring disease activity or 
therapeutic efficacy, and may provide a target for therapeutics in the treatment of pediatric UC. 
CHAPTER II

PLASMABLAST FREQUENCY AND TRAFFICKING RECEPTOR EXPRESSION ARE ALTERED IN PEDIATRIC ULCERATIVE COLITIS

This is the pre-peer-reviewed version of the following article, "Tarlton, N. J., Green, C. M., Lazarus, N. H., Rott, L., Wong, A. P., Abramson, O. N., Bremer, M., Butcher, E. C. and Abramson, T. (2012), Plasmablast frequency and trafficking receptor expression are altered in pediatric ulcerative colitis. Inflamm Bowel Dis. doi: 10.1002/ibd.22962," which has been published online for early view prior to inclusion in the journal at http://onlinelibrary.wiley.com/doi/10.1002/ibd.22962/full. 


\section{Plasmablast Frequency and Trafficking Receptor Expression}

\section{are Altered in Pediatric Ulcerative Colitis}

Nicole J Tarlton ${ }^{1}$, M.S., Caroline M Green ${ }^{1}$, M.S., Nicole H Lazarus ${ }^{2,3}$, Ph.D., Lusijah Rott $^{2,3}$, M.S., Anthony P Wong ${ }^{4}$, M.D., Oren N Abramson ${ }^{4}$, M.D., Martina Bremer 5 , Ph.D., Eugene C Butcher*2,3 ${ }^{* 2}$ M.D., and Tzvia Abramson*1 ${ }^{1}$ Ph.D.

${ }^{1}$ San Jose State University, Department of Biology, One Washington Square, San Jose, CA 95192; ${ }^{2}$ Laboratory of Immunology and Vascular Biology, Department of Pathology, Stanford University School of Medicine, Stanford, California $94305 ;{ }^{3}$ Veterans Affairs Palo Alto Health Care System, Palo Alto, California 94304; ${ }^{4}$ Kaiser Permanente Santa Clara, 710 Lawrence Express Way, Santa Clara, CA 95051; ${ }^{5}$ San Jose State University, Department of Mathematics, One Washington Square, San Jose, CA 95192

* Co-senior authors for this study; both directed this study.

Disclosures: All authors have nothing to disclose.

Correspondent Footnote: Tzvia Abramson, Department of Biological Sciences, One Washington Square, San Jose, CA 95192 (Phone: 408-924-4872; Fax: 408-924-4840; E-mail: tzvia.abramson@sjsu.edu).

Funding: This work was supported by funds from CSUPERB, from NIH grants R37 AI047822, U19 AI090019, and RC1 AI087257, and funds from the Gates Foundation. 


\begin{abstract}
Background: The incidence of pediatric ulcerative colitis (UC), a chronic autoinflammatory disease of the colon, is on the rise. Although an increased infiltration of B cells from the peripheral blood into the colon occurs in UC, B cell trafficking is understudied. We hypothesized that the frequency of circulating plasmablasts (PBs) and their trafficking receptor (TR) expression may be indicative of the location and degree of pathology in pediatric UC. Methods: We conducted multicolor flow cytometry analyses of circulating $\operatorname{IgA}^{+/-}$PBs and $\operatorname{IgA}^{+}$memory B cells (MBCs) in pediatric UC patients with remission, mild, moderate, and severe disease $(n=12)$ and healthy pediatric $(n=2)$ and adult donors $(n=11)$. Results: Compared to healthy donors the average frequency of PBs among total peripheral blood lymphocytes increased 30-fold during severe UC activity and positively correlated with Pediatric Ulcerative Colitis Activity Index score, Creactive protein level, and erythrocyte sedimentation rate. A greater percent of PBs in severe patients expressed the gut-homing receptors $\alpha 4 \beta 7$ and CCR10, and the inflammatory homing molecule P-selectin ligand (P-sel lig). The percent of $\operatorname{IgA}^{+} \mathrm{MBCs}$ expressing $\alpha 4 \beta 7$, however, was reduced. Furthermore, expression of the small intestine TR CCR9 decreased on $\alpha 4 \beta 7^{\text {high }}$ PBs and on $\alpha 4 \beta 7^{\text {high }} / \mathrm{CCR} 10^{\text {high }}$ PBs and MBCs in these patients, consistent with preferential cell targeting to the colon. Conclusions: Peripheral blood PBs with a colon-homing phenotype ( $\alpha 4 \beta 7 / \mathrm{CCR} 10 / \mathrm{P}$-sel lig) were elevated in children with severe UC. Screening this B cell subset may provide a complementary approach in monitoring disease activity or therapeutic efficacy in pediatric UC.
\end{abstract}


Key words: Inflammatory Bowel Disease; memory B cell; plasmablast; trafficking receptor; ulcerative colitis.

Abbreviations used in this thesis: ASC, antibody secreting cell; CLA, cutaneous lymphocyte antigen; CRP, C-reactive protein; ESR, erythrocyte sedimentation rate; HD, healthy donor; IBD, Inflammatory Bowel Disease; MBC, memory B cell; NMS, normal mouse serum; PB, plasmablast; PBMC, peripheral blood mononuclear cell; P-sel lig, Pselectin ligand; PUCAI, Pediatric Ulcerative Colitis Activity Index; SLE, systemic lupus erythematosus; TR, trafficking receptor; UC, ulcerative colitis.

\section{INTRODUCTION}

Inflammatory Bowel Disease (IBD) is a group of chronic autoinflammatory disorders of the gastrointestinal tract, characterized by lesions in the intestinal mucosa. While the precise etiology of IBD remains unclear, it is apparent that a genetic predisposition coupled with environmental triggers leads to an abnormal immunologic

response in the gut ${ }^{1}$. Ulcerative colitis (UC) is an IBD typified by diffuse lesions spread throughout the colon ${ }^{2}$. Although the onset of UC may occur in either childhood or adulthood, pediatric patients often present with a more extensive disease at diagnosis ${ }^{3}$. Furthermore, the incidence of pediatric UC has risen globally ${ }^{4}$, as well as in Northern California $^{5}$, the location of our study.

Intestinal homeostatic conditions are altered in UC, and antibody-secreting cells (ASCs) are implicated in this immunopathology ${ }^{6,7}$. There is an increased infiltration of immature proliferative plasma cells in ulcer bases ${ }^{8}$ and an increased level of IgA and IgG 
ASCs in the colonic mucosa of active UC patients ${ }^{9,10}$. Furthermore, autoantibody production is detected in $\mathrm{UC}$; IgG ASCs from the peripheral blood and colon of UC patients secrete anti-colon antibodies ${ }^{11}$. In patients with inactive disease, increased numbers of ASCs in the colonic lamina propria is a predictive factor of relapse ${ }^{12}$.

While it is clear that B cells contribute to UC, the mechanism controlling their migration to the affected tissue is not fully understood and is especially understudied in pediatric UC. Under homeostatic conditions, B cells circulate through lymphoid tissues to develop and sustain an immune defense. Their recirculation is tightly controlled by the sequential association of adhesion molecules with integrin receptors and chemo-attractant "trafficking receptors" (TRs) expressed on the B cell surface ${ }^{13}$. Unique combinations of TRs direct circulating B cells to specific tissues ${ }^{14}$. For instance many IgA ${ }^{+}$ASCs express TRs that can direct their homing to the intestines, including $\alpha 4 \beta 7$, an integrin receptor for the mucosal vascular addressin MAdCAM- ${ }^{15}$, and CCR9 and/or CCR10, chemoattractant receptors for the small intestine chemokine CCL25 and the common mucosal chemokine CCL28, which is highly expressed in the colon ${ }^{14,16,17}$.

Peripheral blood plasmablasts are proliferating, immature precursors of tissue plasma cells, and thus may be indicative of disease activity in the colon of UC patients. While healthy adults and children maintain low levels of PBs in the peripheral blood ${ }^{18,19}$, these levels rise during natural infection ${ }^{20}$, after vaccination ${ }^{21}$, in bacterial septicemia and liver cirrhosis ${ }^{22}$, in children and adults with active systemic lupus erythematosus $(\mathrm{SLE})^{19,22}$, and in adults with active $\mathrm{IBD}^{23}$. In this study we hypothesize that the percentage and TR phenotype of peripheral blood PBs will reflect the disease severity 
and location of pathology in pediatric UC. Thus, we compared the frequency of peripheral blood B cell subsets and their associated TR expression in UC patients with different disease activity and healthy donors. Through multicolor flow cytometry analysis we show an increased percent of $\operatorname{IgA}^{+/-}$PBs expressing $\alpha 4 \beta 7$, CCR10, and Pselectin binding epitopes in the peripheral blood of children with severe UC. This TR phenotype may be indicative of the mechanism of migration of these cells to the inflamed colon.

\section{ETHICAL CONSIDERATIONS}

This study was performed with IRB approval from Kaiser Permanente (IRB\# CN09AWong-01-H) and San José State University (IRB\# S0902237). All blood samples used in this study were obtained with informed consent.

\section{MATERIALS AND METHODS}

\section{Experimental design and subjects}

Pediatric UC patients were enrolled in this study by pediatric gastroenterologists at Kaiser Permanente in Northern California, who used clinical lab tests, endoscopy/colonoscopy, histopathology, and radiology findings to establish a diagnosis of UC. Disease activity was assessed using the Pediatric Ulcerative Colitis Activity Index (PUCAI) ${ }^{24}$, and patients were grouped according to disease severity for analysis (Table 1). Peripheral blood samples were obtained from the patients during routine blood-work or prior to anti-TNF- $\alpha$ infusion therapy. Twelve pediatric UC patients 
participated in this study. A second sample was obtained from five patients during a different severity of disease and/or at a different time point than their first donation, for a total of seventeen peripheral blood patient samples processed for this study. There were six female and six male patients, ranging from 8-16 years of age (mean of 13). Samples were grouped for analysis according to the patient's disease severity at the time of the blood draw, as outlined in Table $\mathbf{1 .}$

TABLE 1. List of pediatric UC patients and sample information

\begin{tabular}{|c|c|c|c|c|c|c|c|}
\hline Sample & $\begin{array}{c}\text { PUCAI } \\
\text { score }(0-85)\end{array}$ & $\begin{array}{l}{ }^{\text {E} P U C A I ~ d i s e a s e ~} \\
\text { activity group }\end{array}$ & Age (years) & $\begin{array}{l}\text { Gender } \\
\text { (M/F) }\end{array}$ & ESR & CRP & Treatment \\
\hline 1 & 0 & ${ }^{¥}$ Remission & 12 & $\mathrm{M}$ & 9 & 0.2 & ${ }^{* *}$ Methotrexate \\
\hline$\xi_{2}$ & 10 & Mild & 16 & $\mathrm{M}$ & 3 & 0.1 & ${ }^{* * *}$ Remicade \\
\hline 3 & 10 & Mild & 9 & $\mathrm{~F}$ & 33 & 0.1 & ${ }^{* *}$ Imuran, ${ }^{*} 5 \mathrm{ASA}$ \\
\hline 4 & 15 & Mild & 16 & M & 51 & 1.6 & ${ }^{\star * *}$ Humira \\
\hline$\S 5$ & 20 & Mild & 8 & $M$ & 13 & 0 & *Steroids \\
\hline$\xi_{6}$ & 20 & Mild & 16 & $M$ & 8 & 0.1 & ${ }^{* * *}$ Remicade \\
\hline 7 & 25 & Mild & 15 & $F$ & 35 & 0 & $\begin{array}{l}{ }^{* * *} \text { Remicade } \\
{ }^{* \star} \text { Imuran }\end{array}$ \\
\hline 8 & 30 & Mild & 15 & $\mathrm{~F}$ & 24 & 0.1 & ${ }^{*}$ Steroids \\
\hline 9 & 35 & Moderate & 15 & $F$ & 31 & 0 & ${ }^{*} 5 \mathrm{ASA}$ \\
\hline 10 & 50 & Moderate & 15 & $F$ & 13 & 0.2 & $\begin{array}{c}{ }^{*} 5 \mathrm{ASA},{ }^{*} \text { Steroids, } \\
\text { and }{ }^{* *} 6 \mathrm{MP} \text { before } \\
{ }^{* * *} \text { Remicade }\end{array}$ \\
\hline$\dagger 11$ & 60 & Moderate & 9 & M & 40 & 0.8 & ${ }^{* * *}$ Humira \\
\hline${ }^{\dagger} 12$ & 65 & Severe & 9 & $\mathrm{M}$ & 39 & 0.8 & ${ }^{* * *}$ Humira \\
\hline${ }^{\circ} 13$ & 65 & Severe & 15 & M & 29 & 3.7 & ${ }^{* * *}$ Remicade \\
\hline$\S 14$ & 75 & Severe & 8 & M & 87 & 2.3 & *Steroids \\
\hline ‡15 & 75 & Severe & 15 & $\mathrm{~F}$ & 48 & 4.2 & ${ }^{* * *}$ Remicade \\
\hline${ }^{\circ} 16$ & 75 & Severe & 15 & M & 85 & 6.9 & ${ }^{\star * *}$ Remicade \\
\hline ‡17 & 75 & Severe & 15 & $\mathrm{~F}$ & 71 & 3.9 & ${ }^{\star * *}$ Remicade \\
\hline
\end{tabular}

$£$ Activity group is based on PUCAI user guide (score range from 0-85): Remission, $<10$; Mild, 10-34; Moderate, 35-64; Severe, $\geq 65$.

$¥$ The remission group was excluded from most analyses due to the small sample size, which precluded the use of statistical analyses on this patient as a group.

*Anti-inflammatory agents: 5ASA and steroids.

**Immunomodulators: Imuran, Methotrexate, and 6MP.

***Biological therapies: anti-TNF- $\alpha$ monoclonal antibodies, Humira and Remicade. $\xi, \S, \dagger, \delta, \ddagger$ Samples with the same symbol were obtained from the same patient. $M$ male, $F$ female, ESR erythrocyte sedimentation rate, CRP C-reactive protein, 5ASA 5aminosalicylic acid, 6MP 6-mercaptopurine. 
Healthy donors were selected for this study based on lack of IBD disease as well as any other illness (gastrointestinal, respiratory, etc.) for at least one month prior to blood collection. A total of thirteen different healthy donors (two pediatric and eleven adult) participated in this study—-ten female and three male—ranging from 15-47 years of age (mean of 32). One sample per healthy donor was used.

\section{Lymphocyte separation from whole blood}

Heparinized peripheral blood samples were obtained via venipuncture from the different donor populations: $10 \mathrm{ml}$ from pediatric UC patients ( $\mathrm{n}=17)$ and $20 \mathrm{ml}$ from healthy donors ( $\mathrm{n}=13)$. Blood samples were processed using Ficoll (Histopaque-1077, Sigma-Aldrich, St. Louis, MO) density gradient centrifugation, and the peripheral blood mononuclear cell (PBMC) layer was extracted. PBMCs were washed twice in HBSS

without $\mathrm{Ca}^{++} / \mathrm{Mg}^{++}$, and were resuspended in staining buffer (1X PBS with $2 \% \mathrm{FCS}$ and $0.1 \%$ sodium azide). Cells were blocked overnight with normal human serum (H4522, Sigma-Aldrich) and normal goat serum (Gibco, Invitrogen by Life Technologies, Carlsbad, CA), and cells were then stained and acquired.

\section{Monoclonal antibodies for flow cytometry phenotypic analysis}

Primary conjugated antibodies: mouse anti-human CD38 PE-Cy7 (Clone HB7, BD Biosciences, San Jose, CA), goat $\mathrm{F}\left(\mathrm{ab}^{\prime}\right)_{2}$ anti-human IgA FITC (Invitrogen), mouse anti-human CD19 Alexa Fluor 700 (Clone HIB19, BD Biosciences), rat anti-human 
CD49f PE-Cy5 (Clone GoH3, BD Biosciences), and mouse anti-human CD4 V500 (Clone RPA-T4, BD Biosciences).

Primary unconjugated antibodies: mouse anti-human CCR9 (ATCC, Manassas, VA) and anti-human CCR10 (courtesy Dr. Dulce Soler-Ferran, Millennium Pharmaceuticals, Cambridge, MA) were labeled in-house using goat $\mathrm{F}\left(\mathrm{ab}{ }^{\prime}\right)_{2}$ anti-mouse Pacific Blue (Invitrogen) and goat $\mathrm{F}\left(\mathrm{ab}^{\prime}\right)_{2}$ anti-mouse Qdot655 (Invitrogen), respectively. Mouse anti-human $\alpha 4 \beta 7$ (Act-1, ATCC) was PE conjugated by Chromoprobe (St. Louis, MO). Recombinant human P-selectin Fc chimera (R\&D Systems, Minneapolis, MN) was labeled in-house with the Zenon Alexa Fluor 647 human IgG labeling kit (Invitrogen). Biotin rat anti-human CLA (cutaneous lymphocyte antigen, Clone HECA-452, BD Biosciences) was labeled in-house with Streptavidin Qdot565 (Invitrogen).

\section{Cell staining and flow cytometry analysis}

PBMCs $\left(3 \times 10^{6}\right.$ per donor sample) were stained with the previously mentioned antibodies. First, cells were stained with primary anti-CCR9 antibody, washed, and labeled with secondary anti-mouse Pacific Blue. After a second wash, cells were blocked with normal mouse serum (NMS, Santa Cruz Biotechnology, Santa Cruz, CA). Next primary anti-CCR10 antibody was labeled with secondary anti-mouse Qdot655 and was then added to the cells. A bench-top conjugation with P-selectin and Zenon AF647 was performed, and the conjugate was added to the cells to stain P-selectin ligand (P-sel lig). A cocktail of the primary conjugated antibodies was then applied to the cells. 
Subsequently, cells were stained with primary anti-CLA biotin antibody, washed, and labeled with Streptavidin Qdot565. Then a final wash was performed.

Alongside the donor sample, an isotype control with $3 \times 10^{6}$ PBMCs was prepared for the four primary antibodies labeled in-house, using the second stage alone of n-1 (addition of Pacific Blue without CCR9, Qdot655 without CCR10, and Qdot565 without CLA), and an incubation of the cells with 0.5M EDTA (to interrupt the binding of P-sel with P-sel lig). In addition, 10\% NMS was added in place of the primary antibodies CCR9, CCR10, and CLA. Apart from these modifications, the isotype control was prepared in the same manner as the donor sample. All samples were acquired on a BD Biosciences LSRII flow cytometer (in the Butcher lab at Stanford University) using FACSDiva software.

Flow cytometry data were analyzed using FlowJo software (Tree Star Inc., Ashland, OR). TR gates were placed based on the isotype controls or a bimodal comparison of the positive and negative staining populations. During data analysis, positive staining in the isotype control for CCR9, CCR10, P-sel lig, and CLA was subtracted from the donor sample value to account for non-specific binding.

\section{Statistical analysis}

Differences in the percent of $\operatorname{IgA}^{+/-}$PBs and $\operatorname{IgA}^{+}$MBCs between the pediatric $(n=2)$ and adult $(n=11)$ healthy donors were analyzed using the Wilcoxon test. In addition, relationships between the demographic variables of the UC patients (age, gender, and drug treatment) and the response variables $\operatorname{IgA}^{+} \mathrm{PBs}, \operatorname{IgA}^{-} \mathrm{PBs}$, and $\operatorname{IgA}^{+}$ 
MBCs were investigated. To determine whether there is a relationship between the age of the patient and the response levels, we regressed the responses individually on age and tested for zero slope in regression with a regression F-test. To test whether the gender of the patients has an influence on the responses, we used Wilcoxon's test. To test whether the mean responses of the patients vary by the treatment regimen they are subjected to, we performed an analysis of variance (ANOVA F-test). For this analysis the patients were placed into three groups based on treatment: anti-inflammatory agents, immunomodulators, and biological therapies (therapies detailed in Table 1). If the patient was treated with multiple therapies the patient was placed in a treatment group based on the strongest therapy received (anti-inflammatory agents $<$ immunomodulators $<$ biological therapies). All other statistical analyses were performed using Student's $t$-test or linear regression analysis, as identified in the Results section. A $p<0.05$ value was considered statistically significant.

\section{RESULTS}

\section{Peripheral blood B cell subsets in pediatric UC patients}

Circulating plasmablasts (PBs) are in transit to the tissue, where they mature into antibody-secreting cells (ASCs); thus, an increased quantity in the peripheral blood may indicate disease activity in the colon of UC patients. Memory B cells (MBCs) are an immunologic surveillance population that reflect past antigen encounter, and comprise a pool of cells from which PBs specific to previously encountered antigens may be derived. 
We monitored the percent of $\operatorname{IgA}^{+} \mathrm{PBs}$, $\operatorname{IgA}^{-} \mathrm{PBs}$, and $\operatorname{IgA}^{+} \mathrm{MBC}$ in the peripheral blood, to determine whether these B cell subsets were increased in pediatric UC.

Three B cell populations were gated from the PBMCs (Figure 1A-C):

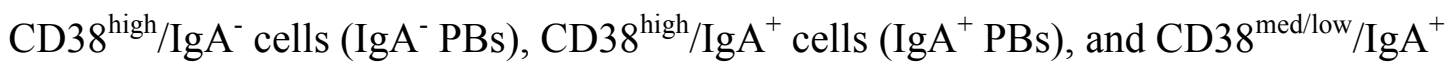
cells (IgA $\mathrm{MBCs}^{+}{ }^{20}$. IgA $\mathrm{A}^{+}$MBCs were further gated to select for CD19 expression. $\mathrm{CD}^{+}$cells were gated out to exclude them from analysis. There was no difference in the frequency of $\operatorname{Ig} \mathrm{A}^{+} \mathrm{PBs}$ between pediatric $(0.11 \%)$ and adult $(0.08 \%)$ healthy donors (Wilcoxon test, $\mathrm{p}=0.23$ ), or in the frequency of $\operatorname{IgA}^{-} \mathrm{PBs}$ ( 0.05 and $0.08 \%$ respectively, $\mathrm{p}=0.92)$ or $\operatorname{IgA}^{+} \mathrm{MBCs}(0.47$ and $0.62 \%, \mathrm{p}=0.77)$ (data not shown). Therefore all healthy donors were combined for statistical comparisons.

Pediatric UC patients with severe disease had a greater percent of $\operatorname{IgA}{ }^{+} \mathrm{PBs}$ among total peripheral blood lymphocytes $(2.48 \%)$ than healthy controls $(0.09 \%$, $\mathrm{p}=0.02)$, as well as patients with mild $(0.26 \%, \mathrm{p}=0.02)$ and moderate $(0.16 \%, \mathrm{p}=0.02)$ disease activity (Figure 1D). While the percent of $\operatorname{Ig}^{-} \mathrm{PBs}$ was greater in severe $\mathrm{UC}$ patients $(2.54 \%)$ compared to other groups, this difference was not statistically significant (Figure 1E). However, when a severe patient who had 7.6\% $\operatorname{Ig} \mathrm{A}^{-} \mathrm{PBs}$ (a high outlier) was removed from the analysis, the percent of $\operatorname{IgA}^{-} \mathrm{PBs}$ in severe patients $(1.5 \%)$ was greater than that in healthy donors $(0.07 \%, \mathrm{p}=0.03)$, mild $(0.23 \%, \mathrm{p}=0.048)$ and moderate $(0.18 \%, \mathrm{p}=0.04) \mathrm{UC}$ patients. In contrast to the PBs, the percent of $\operatorname{Ig} \mathrm{A}^{+} \mathrm{MBC}$ s was similar between healthy and UC patient groups (average range from $0.5-1.2 \%, \mathrm{p}>0.05$ for all comparisons) (Figure 1F). 

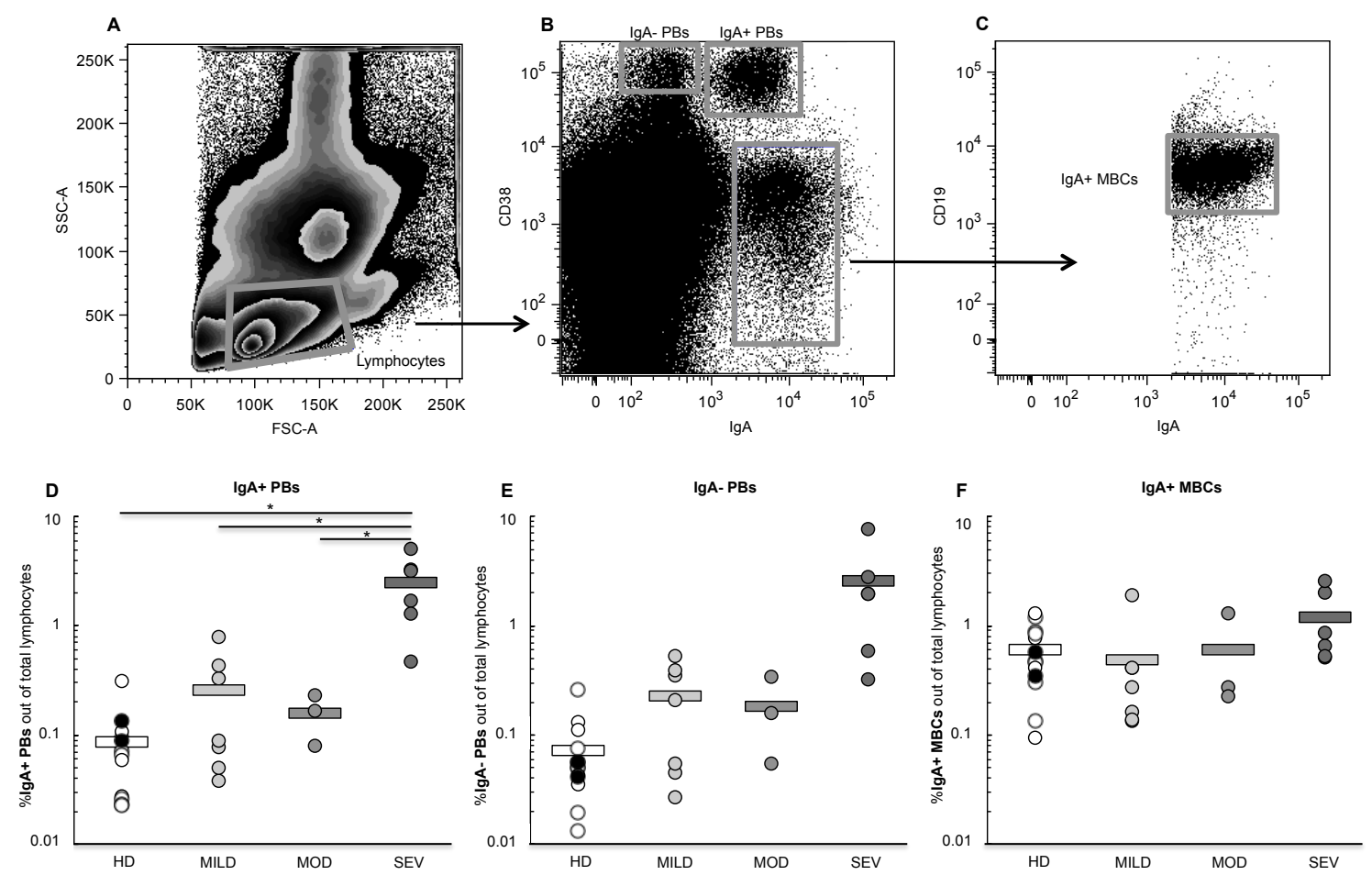

FIGURE 1. Representative flow cytometry plots of $B$ cell subset gating strategy. From left to right: (A) lymphocytes are gated, (B) three B cell subsets are identified - the IgA ${ }^{-}$ plasmablasts (PBs), the $\operatorname{IgA}^{+} \mathrm{PBs}$, and the $\operatorname{IgA}^{+}$memory $\mathrm{B}$ cells (MBCs), then $(\mathrm{C})$ the $\operatorname{IgA}^{+} \mathrm{MBCs}$ are further gated for $\mathrm{CD} 19$ expression. The percent of (D) $\operatorname{Ig} \mathrm{A}^{+} \mathrm{PBs},(\mathrm{E})$ IgA ${ }^{-} \mathrm{PBs}$, and (F) $\operatorname{Ig} \mathrm{A}^{+} \mathrm{MBCs}$ out of total peripheral blood lymphocytes was determined for all healthy donor and pediatric UC patient blood samples. Samples were grouped according to type of donor; groups here are healthy donors (HD) (black dots are pediatric $\mathrm{HD}$, and white dots are adult HD), and pediatric patients with mild UC (MILD), moderate UC (MOD), and severe UC (SEV) disease activity. Circles represent individual samples and bars represent the group's average. Student's $t$-test was performed between all UC patient groups vs. healthy donors, and between the severe group vs. the mild and moderate UC groups. ${ }^{*} p<0.05$; no asterisk indicates $p>0.05$. Significance $(p<0.05)$ is present in (E) when the severe patient with the highest percent of $\mathrm{IgA}^{-} \mathrm{PBs}$ (a high outlier) is removed from the analysis.

Within the UC patients, there was no correlation between age of the patient and percent of $\operatorname{Ig} \mathrm{A}^{+} \mathrm{PBs}$ (regression F-test, $\mathrm{p}=0.93$ ), $\operatorname{IgA}^{-} \mathrm{PBs}(\mathrm{p}=0.67)$, or $\operatorname{Ig} \mathrm{A}^{+} \mathrm{MBCs}$ $\left(\mathrm{p}=0.31\right.$ ), or between the gender of the patient and the percent of $\operatorname{IgA}{ }^{+} \mathrm{PBs}$ (Wilcoxon test, $\mathrm{p}=0.35), \operatorname{IgA}^{-} \mathrm{PBs}(\mathrm{p}=0.92)$, or $\operatorname{Ig} \mathrm{A}^{+} \mathrm{MBCs}(\mathrm{p}=0.92)$ (data not shown). 
Additionally, no significant difference was observed in the mean percent of $\operatorname{IgA} \mathrm{A}^{+} \mathrm{PBs}$ between the patients being treated with anti-inflammatory agents, immunomodulators, or biological therapies (ANOVA F-test, $\mathrm{p}=0.62)$, or in the percent of $\operatorname{Ig} \mathrm{A}^{-} \mathrm{PBs}(\mathrm{p}=0.72)$ and $\operatorname{IgA}^{+} \mathrm{MBCs}(\mathrm{p}=0.56)$ (data not shown).

\section{Correlation between circulating plasmablasts and clinical parameters in pediatric UC patients}

Inflammatory activity in pediatric UC patients is closely monitored using clinical lab tests such as $\mathrm{C}$-reactive protein (CRP) and erythrocyte sedimentation rate (ESR). In addition, the PUCAI scoring system is an assessment tool that provides a way to quantify UC disease severity based on reported symptoms.

Both CRP and ESR values positively correlate with PUCAI score in pediatric UC patients (Figure 2) $(\mathrm{R}=0.72$ and $\mathrm{R}=0.71$ respectively). The percent of peripheral blood $\operatorname{IgA}^{+} \mathrm{PBs}$, and to a lesser degree $\operatorname{Ig} \mathrm{A}^{-} \mathrm{PB}$, correlate with PUCAI score at a comparable level to these established clinical tests ( $\mathrm{R}=0.67$ and $\mathrm{R}=0.54$ respectively). In addition, the percent of $\operatorname{Ig} \mathrm{A}^{+} \mathrm{PBs}$ in circulation correlates very well with $\mathrm{CRP}(\mathrm{R}=0.89)$ and with ESR $\left(\mathrm{R}=0.74\right.$ ), while the percent of $\operatorname{Ig} \mathrm{A}^{-} \mathrm{PBs}$ correlates well, but to a lesser extent (with CRP $\mathrm{R}=0.87$, and with $\mathrm{ESR} \mathrm{R}=0.62$ ). Overall, the frequency of $\operatorname{IgA} \mathrm{A}^{+} \mathrm{PBs}$ in the peripheral blood correlated well, and better, than the $\operatorname{IgA}^{-} \mathrm{PBs}$ with each of the tested parameters (data not shown for IgA PBs or ESR). 

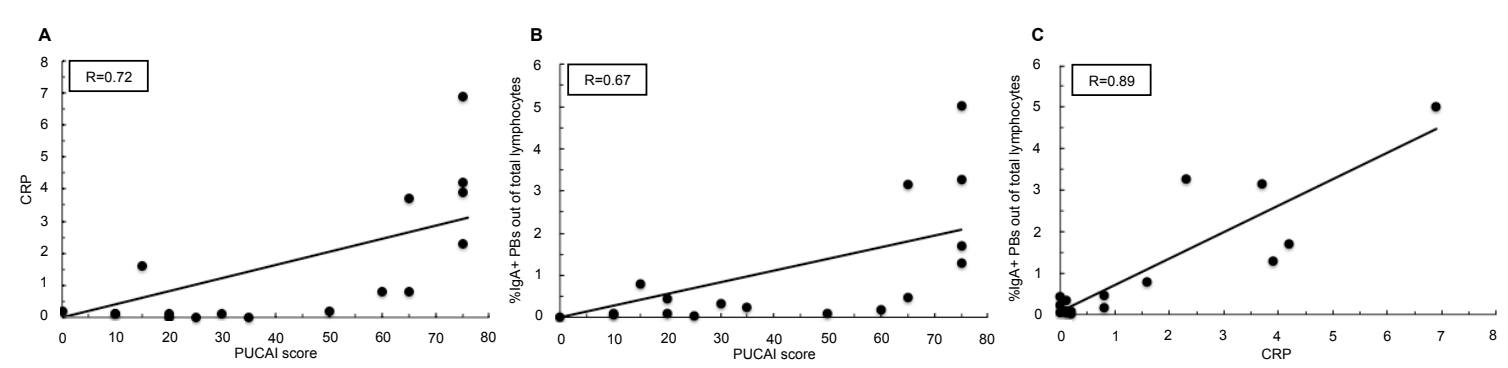

FIGURE 2. Linear regression analyses in pediatric patients with UC. (A) Correlation between serum C-reactive protein (CRP) levels and PUCAI score. (B) Correlation between percent of $\operatorname{Ig} \mathrm{A}^{+}$plasmablasts (PBs) out of total peripheral blood lymphocytes and Pediatric Ulcerative Colitis Activity Index (PUCAI) score. (C) Correlation between percent of IgA $\mathrm{A}^{+} \mathrm{PBs}$ out of total peripheral blood lymphocytes and CRP.

\section{Single trafficking receptor analysis of plasmablasts}

Previous studies indicate that expression of the TR ligands MAdCAM-1 and CCL28, and the vascular receptor P-selectin, is increased in the inflamed colon tissue of UC patients ${ }^{25,26,27}$. Thus, we determined whether circulating PBs in UC patients demonstrated an altered expression of the corresponding TRs, $\alpha 4 \beta 7$ and CCR10, and Psel lig, respectively. In addition CCR9 (a TR with particular relevance to small intestine homing but not colon homing ${ }^{16,28}$ ) was examined. Since extraintestinal manifestations may occur in patients with IBD, we also measured the expression of the skin homing receptor $\mathrm{CLA}^{29}$, a carbohydrate ligand for vascular E-selectin, and the integrin $\alpha 6$ chain (i.e. CD49f), whose expression is associated with homing to the skin, lung, and other

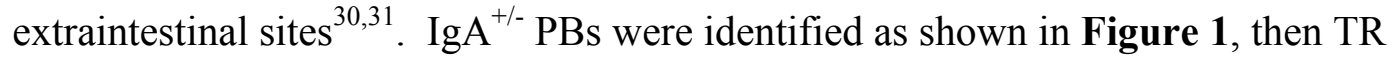
expression was examined using the gating strategy in Figure 3A.

Severe UC patients displayed a greater percent of $\alpha 4 \beta 7^{\text {high }} \operatorname{IgA} A^{+} \mathrm{PBs}\left(69 \%\right.$ of $\operatorname{IgA}{ }^{+}$ PBs) in circulation than healthy donors $(43 \%, \mathrm{p}=0.002)$ and moderate patients $(46 \%$, $\mathrm{p}=0.001$ ) (Figure 3B). Similarly, the percent of CCR $10^{\text {high }} \operatorname{IgA}^{+}$PBs was increased in 

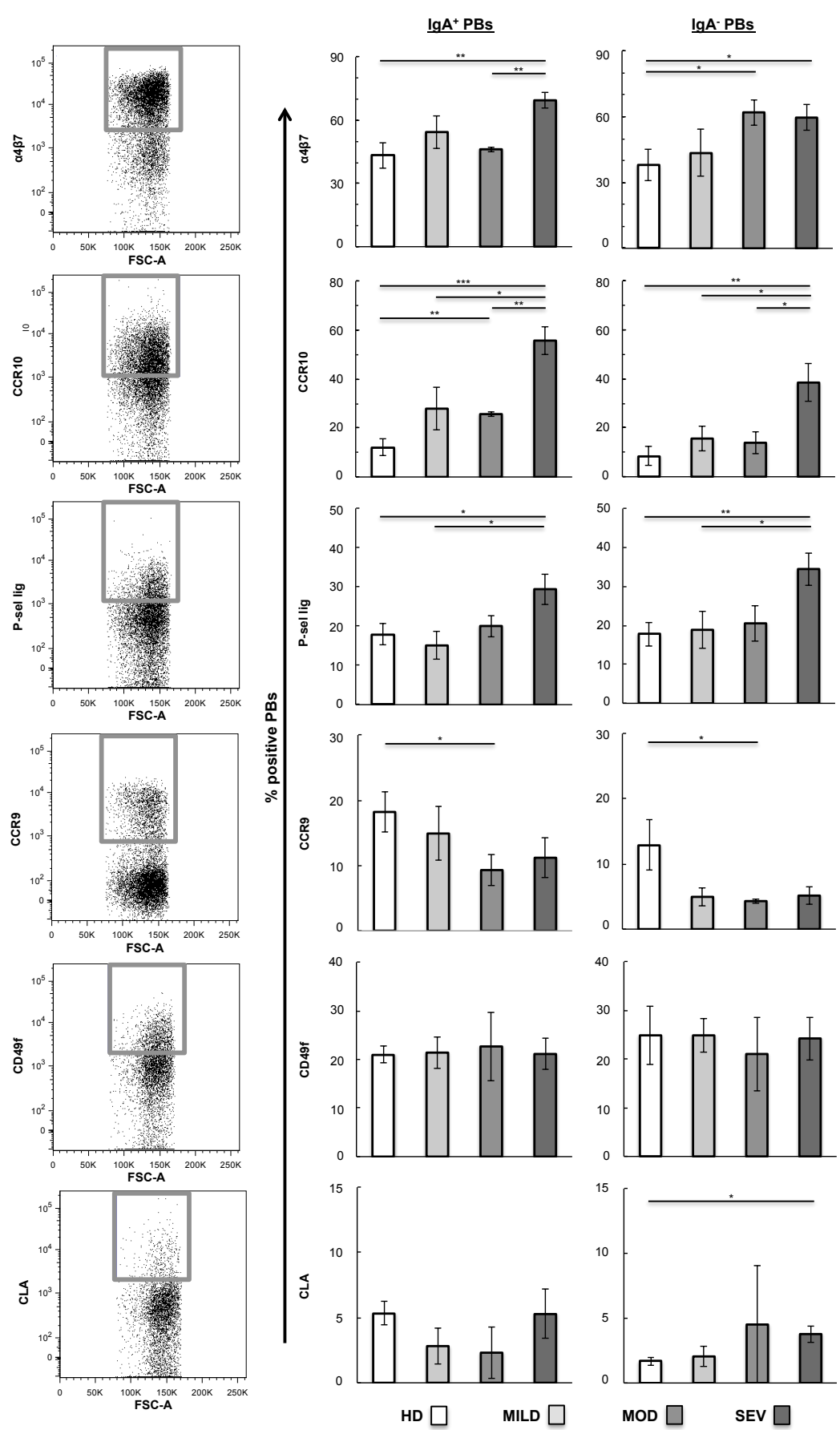

FIGURE 3. Single trafficking receptor (TR) analysis on $\operatorname{IgA}^{+/-}$plasmablasts (PBs). (A) Representative flow cytometry dot plots of individual TR expression on PBs. Gates represent high-TR-expressing cells. Average percent of (B) $\operatorname{IgA}^{+} \mathrm{PBs}$ and (C) $\operatorname{IgA}{ }^{-} \mathrm{PBs}$ with $\mathrm{TR}^{\text {high }}$ expression of $\alpha 4 \beta 7$, CCR10, P-selectin ligand (P-sel lig), CCR9, CD49f, or CLA. Student's $t$-test was performed between all UC patient groups vs. healthy, and between the severe group vs. the mild and moderate UC groups. ${ }^{*} \mathrm{p}<0.05,{ }^{*} \mathrm{p}<0.01$, $* * * \mathrm{p}<0.001$; no asterisk indicates $\mathrm{p}>0.05$. 
severe UC patients ( $56 \%$ of $\left.\operatorname{IgA}^{+} \mathrm{PBs}\right)$ compared to healthy donors $(12 \%, \mathrm{p}=0.0001)$, and patients with mild $(28 \%, \mathrm{p}=0.02)$ and moderate $(26 \%, \mathrm{p}=0.003)$ disease. Furthermore, Psel lig ${ }^{\text {high }} \operatorname{IgA}^{+}$PBs were more frequent in severe UC patients ( $29 \%$ of $\left.\operatorname{IgA}^{+} \mathrm{PBs}\right)$ compared to healthy donors $(18 \%, \mathrm{p}=0.03)$ and patients with mild disease $(15 \%, \mathrm{p}=0.02)$. The IgA- PBs demonstrated similar trends to the $\operatorname{IgA}^{+}$PBs for all three TRs (Figure 3C).

On average UC patients had fewer CCR $9^{\text {high }}$ PBs than HDs, and UC patients with moderate disease demonstrated significantly less CCR $9^{\text {high }} \operatorname{IgA}^{+}$and $\operatorname{IgA}^{-}$PBs ( 9 and $4 \%$ respectively) than healthy donors ( 18 and $13 \%, \mathrm{p}=0.04$ and $\mathrm{p}=0.048$, respectively). The percent of CD499 ${ }^{\text {high }}$ and CLA ${ }^{\text {high }}$ PBs was mainly similar between groups.

\section{Trafficking receptor expression on mucosal and non-mucosal}

\section{plasmablasts}

The combinatorial expression of TRs drives cell homing to the intestines and other sites ${ }^{13}$. Since we observed an increase in PBs that express CCR10 and P-sel lig in severe UC, we further investigated whether this correlated with $\alpha 4 \beta 7$ expression and whether this TR expression occurred primarily on the mucosal $\left(\alpha 4 \beta 7^{\text {high }}\right)$ or non-mucosal $\left(\alpha 4 \beta 7^{\text {low }}\right.$ ) homing cells. $\operatorname{IgA}^{+}$and $\operatorname{Ig} \mathrm{A}^{-}$PBs from Figure 1 were segregated into $\alpha 4 \beta 7^{\text {high }}$ and $\alpha 4 \beta 7^{\text {low }}$ populations, then analyzed for the expression of other TRs as shown in Figure 4A.

The percent of mucosal IgA $\mathrm{A}^{+}$PBs with CCR $10^{\text {high }}$ and P-sel ligh ${ }^{\text {high }}$ expression was greater in severe UC patients (59\% and $28 \%$ respectively) than in healthy controls ( $15 \%$, $\mathrm{p}=0.0002$, and $9 \%, \mathrm{p}=0.001$ respectively), and patients with mild $(30 \%, \mathrm{p}=0.03$, and $13 \%$, 
$\mathrm{p}=0.0099)$ and moderate disease $(29 \%, \mathrm{p}=0.004$, and $13 \%, \mathrm{p}=0.01)($ Figure 4B).

Although the percent of CCR $10^{\text {high }}$ cells was similar in the $\alpha 4 \beta 7^{\text {high }}$ and $\alpha 4 \beta 7^{\text {low }} \operatorname{IgA}^{+} \mathrm{PB}$ subsets, P-sel lig had a greater percentage of expression in the non-mucosal cells. Similar expression patterns for CCR10 and P-sel lig were observed in the mucosal and nonmucosal IgA- PBs (Figure 4C).

The frequency of mucosal $\operatorname{IgA}^{+}$PBs with CCR9 $9^{\text {high }}$ expression was decreased in moderate $(16 \%, \mathrm{p}=0.02)$ and severe $(15 \%, \mathrm{p}=0.002) \mathrm{UC}$ patients compared to healthy donors $(36 \%)$; similar trends were observed in the $\operatorname{IgA}^{-}$PBs. The percent of CCR9 $9^{\text {high }}$ non-mucosal PBs was low in all groups, and on average less than 5\% of non-mucosal PBs demonstrated CCR9 $9^{\text {high }}$ expression. The frequency of mucosal IgA ${ }^{+/-}$PBs with CD49f $\mathrm{f}^{\text {high }}$ expression was similar for healthy and UC patient groups (average range between 12-20\%). However, $\alpha 4 \beta 7^{\text {low }}$ non-mucosal PBs with CD49f $\mathrm{f}^{\text {high }}$ expression were consistently increased (average range between $27-32 \%$ ) compared to their $\alpha 4 \beta 7^{\text {high }}$ mucosal homing counterparts.

The cellular expression of $\alpha 4 \beta 7$ and CLA are usually mutually exclusive, as these TRs mediate lymphocyte homing to different sites. Therefore the percent of mucosal PBs that were CLA ${ }^{\text {high }}$ was very low-on average less than $6 \%$ of cells (CLA data not shown). The frequency of CLA ${ }^{\text {high }}$ cells among non-mucosal PBs was also low-on average less than $10 \%$ of cells. 

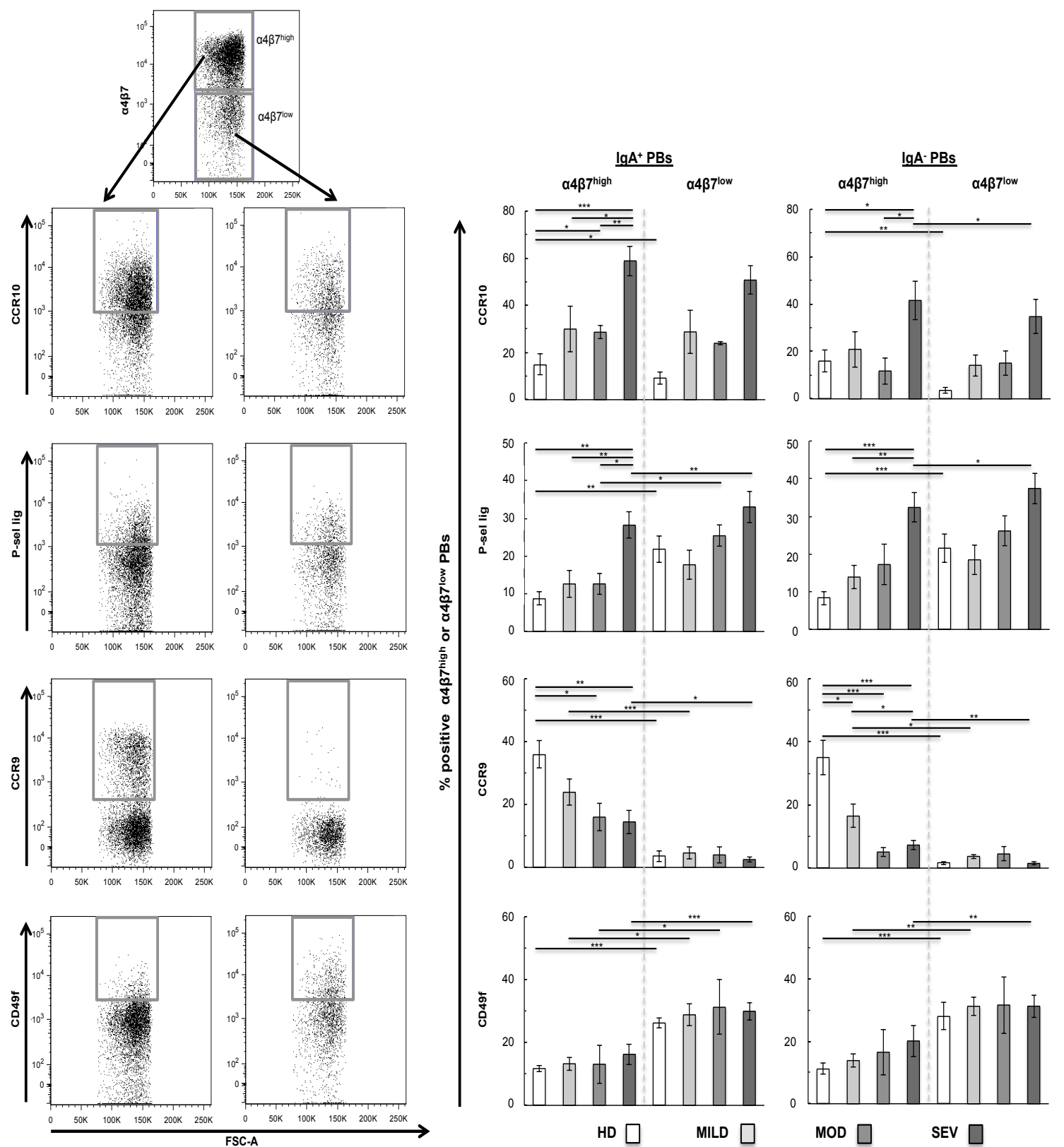

FIGURE 4. Trafficking receptor (TR) analysis on mucosal $\left(\alpha 4 \beta 7^{\text {high }}\right)$ and non-mucosal $\left(\alpha 4 \beta 7^{\text {low }}\right) \mathrm{IgA}^{+/-}$plasmablasts (PBs). (A) Representative flow cytometry plots for TR gating strategy on PBs. From top to bottom: IgA ${ }^{+/-}$PBs are gated for $\alpha 4 \beta 7^{\text {high }}$ expression (upper gate) and $\alpha 4 \beta 7^{\text {low }}$ expression (lower gate), then individual TR expression is examined on each of these subsets. Gates represent cells with $\mathrm{TR}^{\text {high }}$ expression of CCR10, P-selectin ligand, CCR9, or CD49f. Bar graphs display the average percent of $\alpha 4 \beta 7^{\text {high }}$ and $\alpha 4 \beta 7^{\text {low }}$ (B) IgA ${ }^{+}$PBs and (C) IgA IBs with $^{-} R^{\text {high }}$ expression. Statistical analyses for $\alpha 4 \beta 7^{\text {high }}$ cells were performed between all UC patient groups vs. healthy, and between the severe group vs. the mild and moderate UC groups. In addition, statistical analyses were performed between $\alpha 4 \beta 7^{\text {high }}$ and $\alpha 4 \beta 7^{\text {low }}$ cells within groups using Student's $t$-test. ${ }^{*} \mathrm{p}<0.05,{ }^{* *} \mathrm{p}<0.01,{ }^{* * *} \mathrm{p}<0.001$; no asterisk indicates $\mathrm{p}>0.05$. 


\section{Trafficking receptor expression on memory B cells}

MBCs act as an immunological surveillance population, and their presence reflects past antigen encounter. Since UC is a chronic disease, we predicted that TR expression on peripheral blood MBCs may be indicative of the location of past disease activity in UC patients. We compared the TR expression of $\operatorname{IgA}^{+} \mathrm{MBC}$ to their activated counterparts, the $\operatorname{Ig} \mathrm{A}^{+} \mathrm{PBs}$, and also compared $\operatorname{Ig} \mathrm{A}^{+} \mathrm{MBC}$ TR expression between donor groups.

The differential TR expression on $\operatorname{Ig} \mathrm{A}^{+} \mathrm{PBs}$ and MBCs is visually demonstrated in overlay dot plots of the two B cell populations from all severe UC patients (Figure 5A). Co-expression of $\alpha 4 \beta 7$ and CCR10 or P-sel lig was consistently higher on PBs than MBCs. However, the co-expression of $\alpha 4 \beta 7$ and CCR9 or CD49f was more similar between the cell subsets.
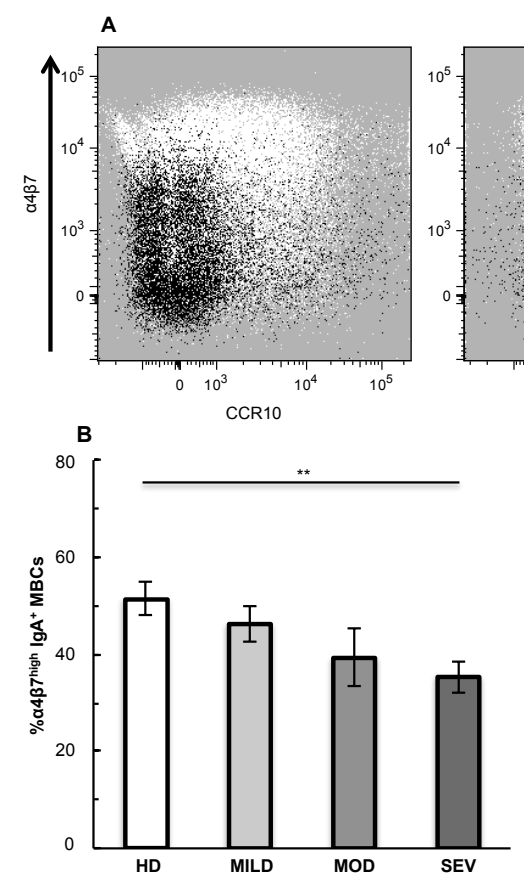
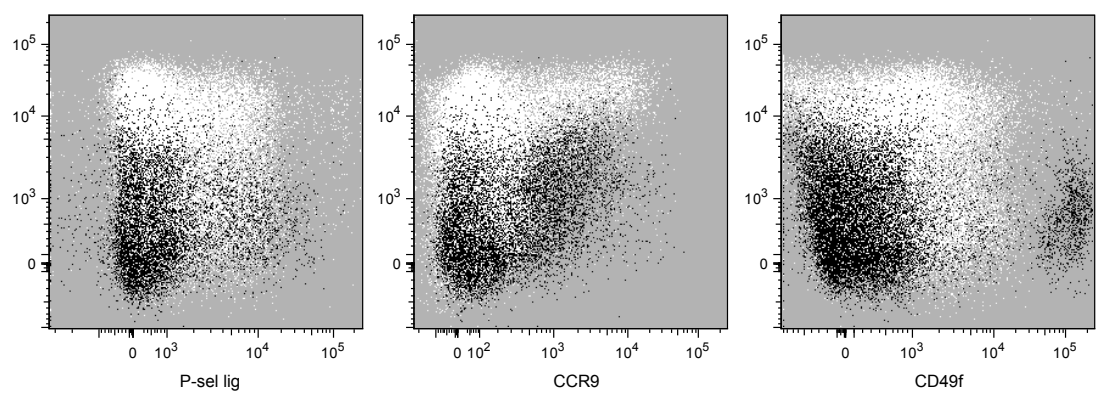

FIGURE 5. Comparison of $\operatorname{IgA} \mathrm{A}^{+}$plasmablasts (PBs) and $\mathrm{IgA}^{+}$memory B cells (MBCs). (A) Flow cytometry dot plot overlays of trafficking receptor (TR) co-expression of $\alpha 4 \beta 7$ with CCR10, P-sel lig, CCR9, or CD49f on IgA ${ }^{+}$ PBs (white dots) and IgA ${ }^{+}$MBCs (black dots) from all severe UC patients combined. (B) Single TR expression on IgA $\mathrm{A}^{+} \mathrm{MBCs}$, showing the average percent of MBCs with $\alpha 4 \beta 7^{\text {high }}$ expression in each donor group. Student's $t$-test was performed between all UC patient groups vs.

healthy, and between the severe group vs. the mild and moderate UC groups. ${ }^{* *} \mathrm{p}<0.01$; no asterisk indicates $\mathrm{p}>0.05$. 
Unlike the PBs, the frequency of CCR $10^{\text {high }}$, P-sel lig ${ }^{\text {high }}, \mathrm{CCR} 9^{\text {high }}$, and CD49f $\mathrm{f}^{\text {high }}$ $\operatorname{Ig} \mathrm{A}^{+} \mathrm{MBCs}$ was similar in healthy donors and UC patients ( $\mathrm{p}>0.05$ for all comparisons; data not shown). However in contrast to the $\alpha 4 \beta 7^{\text {high }} \mathrm{PBs}$, the frequency of $\alpha 4 \beta 7^{\text {high }} \operatorname{IgA}{ }^{+}$ MBCs was decreased in severe UC patients (35\%) compared to healthy donors (51\%, $\mathrm{p}=0.004)($ Figure 5B).

\section{CCR9 expression on B cell subsets co-expressing $\alpha 4 \beta 7$ and CCR10} $\alpha 4 \beta 7$ and CCR10 expression without CCR9 is expected to favor cell homing to the colon, as MAdCAM-1 and CCL28 are highly expressed in the colon, whereas CCR9 and its ligand CCL25 are major determinants of lymphocyte recruitment to the small intestine $^{14}$. Therefore we examined $\alpha 4 \beta 7^{\text {high }} / \mathrm{CCR} 10^{\text {high }} \mathrm{B}$ cell subsets for CCR9 expression.

In general the proportion of $\alpha 4 \beta 7^{\text {high }} / \mathrm{CCR} 10^{\text {high }} \mathrm{PBs}$ and MBCs expressing CCR9 decreased as the severity of UC disease intensified (Figure 6). The frequency of $\alpha 4 \beta 7^{\text {high }} / \mathrm{CCR} 10^{\text {high }} \mathrm{IgA}^{+}$and $\operatorname{IgA} \mathrm{A}^{-}$PBs with CCR9 expression was decreased in the moderate $(23 \%, \mathrm{p}=0.04$, and $8 \%, \mathrm{p}=0.03$ respectively $)$ and severe $(17 \%, \mathrm{p}=0.009$, and $12 \%, p=0.04)$ UC disease activity groups compared to healthy donors (43 and 33\%). In addition, the percent of $\alpha 4 \beta 7^{\text {high }} / \mathrm{CCR} 10^{\text {high }} \operatorname{IgA}{ }^{+}$MBCs expressing CCR9 in severe UC $(30 \%)$ was decreased compared to healthy controls $(50 \%, \mathrm{p}=0.02)$. 


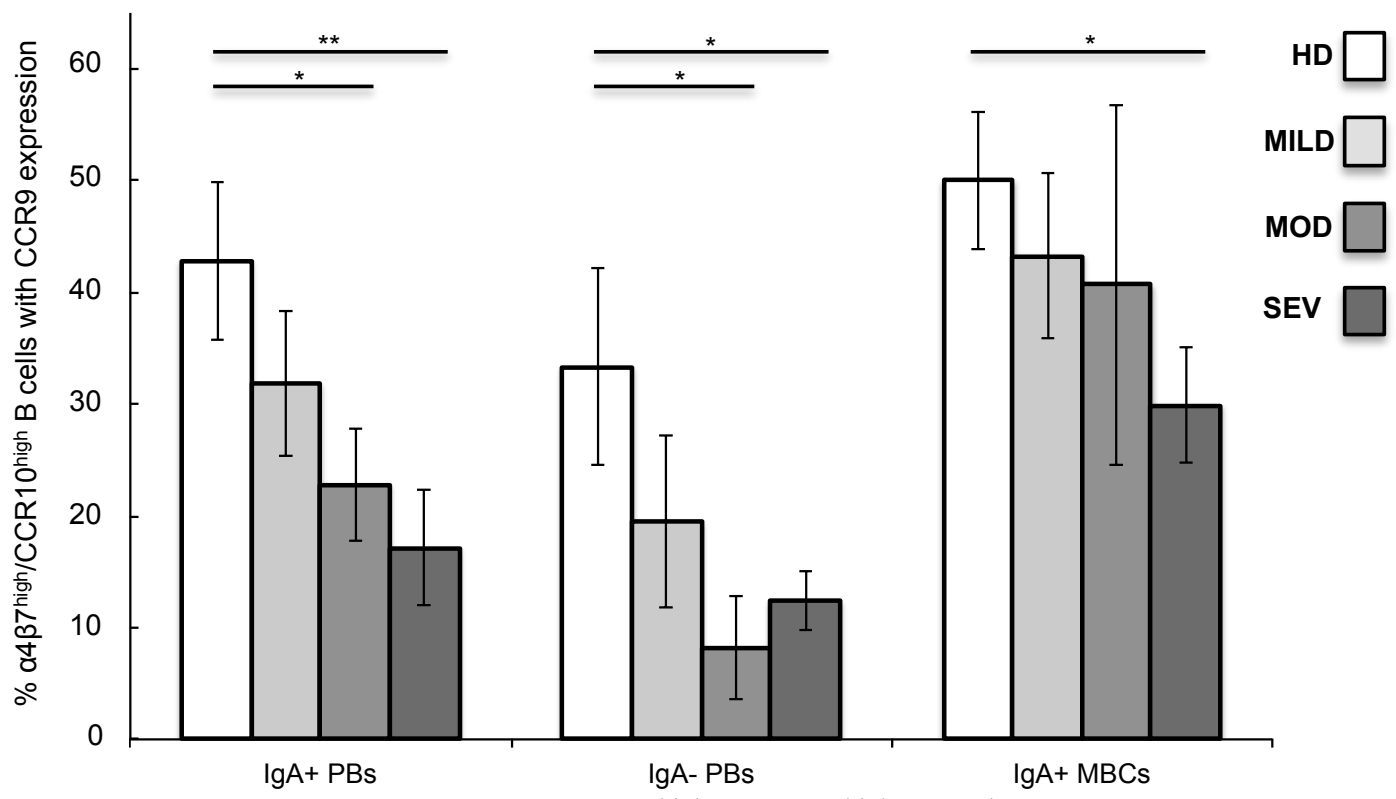

FIGURE 6. CCR 9 expression on $\alpha 4 \beta 7^{\text {high }} / \mathrm{CCR} 10^{\text {high }} \operatorname{IgA} \mathrm{A}^{+/}$plasmablasts (PBs), and IgA ${ }^{+}$memory B cells (MBCs). Samples were grouped according to type of donor: healthy donors (HD) and pediatric patients with mild UC (MILD), moderate UC (MOD), and severe UC (SEV) disease activity. Statistical analyses within each B cell subset were performed between healthy donors and $\mathrm{UC}$ patient disease activity groups using Student's $t$-test. ${ }^{*} \mathrm{p}<0.05$; no asterisk indicates $\mathrm{p}>0.05$.

\section{DISCUSSION}

B lymphocytes contribute to the immunopathology of $\mathrm{UC}^{6,7}$; however, the mechanisms controlling migration to the affected tissue in this disease is understudied. We examined peripheral blood B cell subsets in UC patients using the rationale that their frequency and migratory potential, reflected by their TR expression, would be altered and therefore indicative of B cell activity in the colon. The purpose of this study was to characterize TR expression on B cell subsets, specifically PBs, elicited in UC. We focused our study on pediatric patients with recent onset of illness and hence with fewer confounding effects of comorbidities and long-term medication. 
Here we showed that the average frequency of both $\operatorname{IgA}^{+}$and $\operatorname{IgA}^{-} \mathrm{PBs}$ were elevated in children with severe UC as compared to healthy donors and patients with mild and moderate disease activity. Similar findings have recently been reported by Hosomi et al. ${ }^{23}$ in adult UC patients with active disease. In contrast, the percent of peripheral blood $\operatorname{IgA}^{+} \mathrm{MBCs}$ was unaltered in patients at all disease activity levels compared to healthy individuals — a feature that has been demonstrated in other chronic autoimmune disorders such as pediatric $\mathrm{SLE}^{19}$. Therefore the frequency of peripheral blood PBs, but not MBCs, is a good indicator of disease severity and inflammation in UC.

As the UC disease activity increased in severity, we observed a dramatic increase in the percent of $\operatorname{Ig} \mathrm{A}^{+}$and $\operatorname{IgA}^{-}$PBs with $\alpha 4 \beta 7^{\text {high }}$ and CCR $10^{\text {high }}$ or P-sel ligh ${ }^{\text {high }}$ coexpression, supporting the hypothesis that these TRs play a role in PB migration to the colon in UC. Of note, Hosomi et al. ${ }^{23}$ did not observe an increase in CCR10 expressing PBs (defined as $\mathrm{CD} 19^{+} / \mathrm{CD} 20^{-}$cells) in adult UC. Since all activity levels were combined in their study, perhaps a rise in CCR10 expressing PBs was masked by UC patients with milder disease. Another possibility is that the relevance of CCR10 is different in adult UC vs. pediatric UC, and this TR has greater significance during the initial onset or early in disease.

P-sel lig, along with its corresponding receptor P-selectin, is upregulated in immune cells and on the vascular endothelium in response to inflammation ${ }^{32}$. In this study we observed an increased frequency of both $\alpha 4 \beta 7^{\text {low }}$ and $\alpha 4 \beta 7^{\text {high }}$ PBs expressing Psel lig in severe UC, further indicating the high levels of colon inflammation at this stage 
of disease and perhaps reflecting the massive migration of cells expressing P-sel lig into the inflamed colon.

There was a trend in the mild and moderate activity groups for an increased percent of $\alpha 4 \beta 7^{\text {high }}$ PBs but not CCR $10^{\text {high }}$ and P-sel lig ${ }^{\text {high }}$ cells; only patients with severe disease activity displayed a higher frequency of CCR $10^{\text {high }}$ and P-sel lig ${ }^{\text {high }}$ PBs. It is possible that UC therapeutics decrease certain TR responses, i.e., CCR10 and P-sel lig upregulation on cells. Alternatively, high CCR10 and high P-sel lig expression may be imprinted on PBs only at advanced stages of disease, where intensified exposure to colon antigens has occurred due to extensive inflammation and tissue damage. Thus a rise in the frequency of peripheral blood PBs imprinted with high CCR10 and high P-sel lig expression may reflect a more acute manifestation of UC than does a rise in PBs with high $\alpha 4 \beta 7$ only.

The frequency of $\operatorname{IgA}^{+}$MBCs expressing $\alpha 4 \beta 7$ at high levels decreased as UC disease activity intensified, and severe patients had a lower proportion of these cells compared to healthy donors. $\alpha 4 \beta 7^{\text {high }}$ MBCs may redistribute from the blood to the intestines in response to inflammation or may be re-activated in patients during a flare in disease activity and thus become depleted from the circulating $\alpha 4 \beta 7 \mathrm{MBC}$ pool.

We found a reduced frequency of PBs with CCR $9^{\text {high }}$ expression in pediatric UC, and moderate and severe patients had fewer PBs co-expressing $\alpha 4 \beta 7$ and CCR9. There is no small intestine involvement in UC, a disease that solely affects the colon; therefore no upregulation in CCR9, which preferentially targets lymphocytes to the small intestine, was expected. In severe UC patients, there was also a decrease in the percent of 
$\alpha 4 \beta 7^{\text {high }} / \mathrm{CCR} 10^{\text {high }} \mathrm{PBs}$ and MBCs that express CCR9, which indicates these patients have increased levels of PBs that may preferentially migrate to the colon vs. the small intestine $\mathrm{i}^{33}$

Extraintestinal manifestations may occur in pediatric IBD, and some patients develop pathologies of the skin, liver and other complications ${ }^{34,35}$. The proportion of cells that expressed CLA, a trafficking molecule associated with skin homing, was low on both PBs and MBCs. However, only one of the pediatric UC patients in this study developed a skin pathology, which may explain the low frequency of cells expressing this molecule.

While the role of the integrin receptor CD49f (i.e. $\alpha 6$ ) in UC is not well documented, B cells in the colon of UC patients, but not in the colon of Crohn's or nonIBD patients, were found to express this receptor ${ }^{36}$. In our study the frequency of B cells expressing CD49f was unaltered in UC, and the expression of the receptor was more prominent on $\alpha 4 \beta 7^{\text {low }}$ cells, supporting the idea that CD49f is not associated with guthoming lymphocytes ${ }^{30}$. Our results indicate that CD49f plays a minimal role in B cell trafficking in pediatric UC.

In conclusion, our study demonstrates an increase in the frequency of $\operatorname{Ig} \mathrm{A}^{+}$and $\mathrm{IgA}^{-} \mathrm{PBs}$ in the peripheral blood of severe UC patients. PB frequency positively correlates with UC disease severity and inflammation, indicating circulating PB subsets as a good indicator of disease activity in pediatric UC. In addition, circulating $\operatorname{IgA}^{+/-} \mathrm{PBs}$ with $\alpha 4 \beta 7^{\text {high }} / \mathrm{CCR} 10^{\text {high }} / \mathrm{P}$-sel lig ${ }^{\text {high }}$ expression are elevated in pediatric UC patients with severe disease. In combination these trafficking receptors likely facilitate PB homing to 
the inflamed colonic tissue. Thus, this cell subset may provide a therapeutic target for the treatment of UC, and the surveillance of circulating PBs and their associated TR expression may potentially be used as a non-invasive, complementary approach to monitor disease activity or therapeutic efficacy in children with this disease.

\section{ACKNOWLEDGEMENTS}

We are very thankful to both the patients and healthy donors who participated in this study, without whose contribution this study would not have been possible. We would like to thank Dr. Kenneth Youngman (San José State University) for critical editing of this manuscript. 


\section{REFERENCES}

1. Loftus EV, Jr., Sandborn WJ. Epidemiology of inflammatory bowel disease. Gastroenterol Clin North Am. 2002;31:1-20.

2. Podolsky DK. Inflammatory bowel disease. N Engl J Med. 2002;347:417-29.

3. Langholz E, Munkholm P, Krasilnikoff PA, et al. Inflammatory bowel diseases with onset in childhood. Clinical features, morbidity, and mortality in a regional cohort. Scand J Gastroenterol. 1997;32:139-47.

4. Benchimol EI, Fortinsky KJ, Gozdyra P, et al. Epidemiology of pediatric inflammatory bowel disease: a systematic review of international trends. Inflamm Bowel Dis. 2011;17:423-39.

5. Abramson O, Durant M, Mow W, et al. Incidence, prevalence, and time trends of pediatric inflammatory bowel disease in Northern California, 1996 to 2006. $J$ Pediatr. 2010;157:233-239 e1.

6. Brandtzaeg P, Haraldsen G, Rugtveit J. Immunopathology of human inflammatory bowel disease. Springer Semin Immunopathol. 1997;18:555-89.

7. Brandtzaeg P, Carlsen HS, Halstensen TS. The B-cell system in inflammatory bowel disease. Adv Exp Med Biol. 2006;579:149-67.

8. Jinno Y, Ohtani H, Nakamura S, et al. Infiltration of CD19+ plasma cells with frequent labeling of Ki-67 in corticosteroid-resistant active ulcerative colitis. Virchows Arch. 2006;448:412-21.

9. Keren DF. Autoreactivity and altered immune responses in inflammatory bowel disease. Clin Lab Med. 1988;8:325-36.

10. Yacyshyn BR. Activated CD19+ B cell lamina propria lymphocytes in ulcerative colitis. Immunol Cell Biol. 1993;71 ( Pt 4):265-74.

11. Hibi $\mathrm{T}$, Ohara $\mathrm{M}$, Toda $\mathrm{K}$, et al. In vitro anticolon antibody production by mucosal or peripheral blood lymphocytes from patients with ulcerative colitis. Gut. 1990;31:1371-6.

12. Bitton A, Peppercorn MA, Antonioli DA, et al. Clinical, biological, and histologic parameters as predictors of relapse in ulcerative colitis.

Gastroenterology. 2001;120:13-20. 
13. Butcher EC, Picker LJ. Lymphocyte homing and homeostasis. Science. 1996;272:60-6.

14. Kunkel EJ, Butcher EC. Plasma-cell homing. Nat Rev Immunol. 2003;3:822-9.

15. Berlin C, Berg EL, Briskin MJ, et al. Alpha 4 beta 7 integrin mediates lymphocyte binding to the mucosal vascular addressin MAdCAM-1. Cell. 1993;74:185-95.

16. Hieshima K, Kawasaki Y, Hanamoto $\mathrm{H}$, et al. CC chemokine ligands 25 and 28 play essential roles in intestinal extravasation of IgA antibody-secreting cells. $J$ Immunol. 2004;173:3668-75.

17. Lazarus NH, Kunkel EJ, Johnston B, et al. A common mucosal chemokine (mucosae-associated epithelial chemokine/CCL28) selectively attracts IgA plasmablasts. J Immunol. 2003;170:3799-805.

18. Fernandes JR, Snider DP. Polymeric IgA-secreting and mucosal homing preplasma cells in normal human peripheral blood. Int Immunol. 2010;22:527-40.

19. Odendahl M, Keitzer R, Wahn U, et al. Perturbations of peripheral B lymphocyte homoeostasis in children with systemic lupus erythematosus. Ann Rheum Dis. 2003;62:851-8.

20. Jaimes MC, Rojas OL, Kunkel EJ, et al. Maturation and trafficking markers on rotavirus-specific B cells during acute infection and convalescence in children. $J$ Virol. 2004;78:10967-76.

21. Mei HE, Yoshida T, Sime W, et al. Blood-borne human plasma cells in steady state are derived from mucosal immune responses. Blood. 2009;113:2461-9.

22. Harada Y, Kawano MM, Huang N, et al. Identification of early plasma cells in peripheral blood and their clinical significance. Br J Haematol. 1996;92:184-91.

23. Hosomi S, Oshitani N, Kamata N, et al. Increased numbers of immature plasma cells in peripheral blood specifically overexpress chemokine receptor CXCR3 and CXCR4 in patients with ulcerative colitis. Clin Exp Immunol. 2010;163:215-24.

24. Turner D, Otley AR, Mack D, et al. Development, validation, and evaluation of a pediatric ulcerative colitis activity index: a prospective multicenter study.

Gastroenterology. 2007;133:423-32. 
25. Souza HS, Elia CC, Spencer J, et al. Expression of lymphocyte-endothelial receptor-ligand pairs, alpha4beta7/MAdCAM-1 and OX40/OX40 ligand in the colon and jejunum of patients with inflammatory bowel disease. Gut. 1999;45:856-63.

26. Ogawa H, Iimura M, Eckmann L, et al. Regulated production of the chemokine CCL28 in human colon epithelium. Am J Physiol Gastrointest Liver Physiol. 2004;287:G1062-9.

27. Schurmann GM, Bishop AE, Facer P, et al. Increased expression of cell adhesion molecule P-selectin in active inflammatory bowel disease. Gut. 1995;36:411-8.

28. Papadakis KA, Prehn J, Nelson V, et al. The role of thymus-expressed chemokine and its receptor CCR9 on lymphocytes in the regional specialization of the mucosal immune system. J Immunol. 2000;165:5069-76.

29. Kantele A, Savilahti E, Tiimonen H, et al. Cutaneous lymphocyte antigen expression on human effector B cells depends on the site and on the nature of antigen encounter. Eur J Immunol. 2003;33:3275-83.

30. Mackay CR, Marston WL, Dudler L, et al. Tissue-specific migration pathways by phenotypically distinct subpopulations of memory T cells. Eur J Immunol. 1992;22:887-95.

31. Abitorabi MA, Mackay CR, Jerome EH, et al. Differential expression of homing molecules on recirculating lymphocytes from sheep gut, peripheral, and lung lymph. J Immunol. 1996;156:3111-7.

32. Kansas GS. Selectins and their ligands: current concepts and controversies. Blood. 1996;88:3259-87.

33. Kunkel EJ, Campbell DJ, Butcher EC. Chemokines in lymphocyte trafficking and intestinal immunity. Microcirculation. 2003;10:313-23.

34. Dotson JL, Hyams JS, Markowitz J, et al. Extraintestinal manifestations of pediatric inflammatory bowel disease and their relation to disease type and severity. J Pediatr Gastroenterol Nutr. 2010;51:140-5.

35. Jose FA, Garnett EA, Vittinghoff E, et al. Development of extraintestinal manifestations in pediatric patients with inflammatory bowel disease. Inflamm Bowel Dis. 2009;15:63-8. 
36. Yacyshyn BR, Lazarovits A, Tsai V, et al. Crohn's disease, ulcerative colitis, and normal intestinal lymphocytes express integrins in dissimilar patterns.

Gastroenterology. 1994;107:1364-71. 
CHAPTER III

CONCLUSION 


\section{Conclusions}

Ulcerative colitis (UC) is a serious and life altering disorder for which an effective therapeutic regimen can be difficult to establish. In this work we utilized multicolor flow cytometry analysis to determine the relationship between the frequency of circulating plasmablasts (PBs) and their associated trafficking receptors (TRs) with the severity of disease in the colon in pediatric UC patients. We show here that the percent

of peripheral blood PBs with $\alpha 4 \beta 7^{\text {high }} / \mathrm{CCR} 10^{\text {high }} / \mathrm{P}$-sel lig ${ }^{\text {high }}$ expression are indicative of the severity of disease and location of pathology in pediatric UC.

Our work suggests that circulating PB subsets may provide a useful parameter to monitor in the evaluation of pediatric UC patients' progression of disease and response to treatment. Our complementary approach would provide both a relatively non-invasive and specific method for monitoring the immune system in these patients. The PB subsets and TRs we have indicated here may also provide a therapeutic target for the treatment of $\mathrm{UC}$.

\section{Future Directions}

To further investigate the significance of PBs and their associated TR expression in Inflammatory Bowel Disease (IBD), we plan to expand our research in the following directions:

1. We will expand the panel of TRs examined on PBs to include additional trafficking molecules with relevance in inflammation-for instance the chemokine receptors CXCR3 and CXCR4.

2. We will examine circulating PB subsets in pediatric Crohn's Disease (CD) 
patients. The study of CD will contribute to a greater understanding of TR expression in IBD because patients with CD can experience lesion pathology all throughout the gastrointestinal (GI) tract. For instance, patients may experience lesions in one or many locations, i.e. the large bowel, the small bowel, the upper gastrointestinal tract, or a combination of these. We will compare the TR phenotype of PBs in UC to those in CD patients that demonstrate only colon involvement. We predict that this comparison will have either of two outcomes: TR expression may be the same since the location of tissue involvement is identical in both circumstances, or different TRs may be involved in CD since the appearance of lesions is distinct from that in UC.

3. Although not an IBD, we plan to investigate TR expression on PBs in celiac disease - a GI disorder characterized by localized inflammation/lesions in the small bowel due to gluten protein intolerance. We will compare the TR phenotype of PBs in celiac disease to those in CD patients with small bowel involvement, again to determine if TR expression is the same if the location of tissue involvement is identical, or if different TRs are involved in the two diseases because the appearance of lesions is distinct.

Ultimately, through the comparison of TR expression on PBs in UC, CD, and celiac disease, we aim to develop (or would like to determine if it is possible to develop) a multicolor flow cytometry analysis of TRs that would enable us to distinguish between disease activity and location of pathology in these three inflammatory disorders. 


\section{REFERENCES}

1. Loftus EV, Jr., Sandborn WJ. Epidemiology of inflammatory bowel disease. Gastroenterol Clin North Am. 2002;31:1-20.

2. Podolsky DK. Inflammatory bowel disease. N Engl J Med. 2002;347:417-29.

3. Langholz E, Munkholm P, Krasilnikoff PA, et al. Inflammatory bowel diseases with onset in childhood. Clinical features, morbidity, and mortality in a regional cohort. Scand J Gastroenterol. 1997;32:139-47.

4. Benchimol EI, Fortinsky KJ, Gozdyra P, et al. Epidemiology of pediatric inflammatory bowel disease: a systematic review of international trends. Inflamm Bowel Dis. 2011;17:423-39.

5. Abramson O, Durant M, Mow W, et al. Incidence, prevalence, and time trends of pediatric inflammatory bowel disease in Northern California, 1996 to $2006 . J$ Pediatr. 2010;157:233-239 e1.

6. Brandtzaeg P, Haraldsen G, Rugtveit J. Immunopathology of human inflammatory bowel disease. Springer Semin Immunopathol. 1997;18:555-89.

7. Brandtzaeg P, Carlsen HS, Halstensen TS. The B-cell system in inflammatory bowel disease. Adv Exp Med Biol. 2006;579:149-67.

8. Jinno Y, Ohtani H, Nakamura S, et al. Infiltration of CD19+ plasma cells with frequent labeling of Ki-67 in corticosteroid-resistant active ulcerative colitis. Virchows Arch. 2006;448:412-21.

9. Keren DF. Autoreactivity and altered immune responses in inflammatory bowel disease. Clin Lab Med. 1988;8:325-36.

10. Yacyshyn BR. Activated CD19+ B cell lamina propria lymphocytes in ulcerative colitis. Immunol Cell Biol. 1993;71 ( Pt 4):265-74.

11. Hibi $\mathrm{T}$, Ohara $\mathrm{M}$, Toda $\mathrm{K}$, et al. In vitro anticolon antibody production by mucosal or peripheral blood lymphocytes from patients with ulcerative colitis. Gut. 1990;31:1371-6.

12. Bitton A, Peppercorn MA, Antonioli DA, et al. Clinical, biological, and histologic parameters as predictors of relapse in ulcerative colitis. Gastroenterology. 2001;120:13-20. 
13. Butcher EC, Picker LJ. Lymphocyte homing and homeostasis. Science. 1996;272:60-6.

14. Kunkel EJ, Butcher EC. Plasma-cell homing. Nat Rev Immunol. 2003;3:822-9.

15. Berlin C, Berg EL, Briskin MJ, et al. Alpha 4 beta 7 integrin mediates lymphocyte binding to the mucosal vascular addressin MAdCAM-1. Cell. 1993;74:185-95.

16. Hieshima K, Kawasaki Y, Hanamoto $\mathrm{H}$, et al. CC chemokine ligands 25 and 28 play essential roles in intestinal extravasation of IgA antibody-secreting cells. $J$ Immunol. 2004;173:3668-75.

17. Lazarus NH, Kunkel EJ, Johnston B, et al. A common mucosal chemokine (mucosae-associated epithelial chemokine/CCL28) selectively attracts IgA plasmablasts. J Immunol. 2003;170:3799-805.

18. Fernandes JR, Snider DP. Polymeric IgA-secreting and mucosal homing preplasma cells in normal human peripheral blood. Int Immunol. 2010;22:527-40.

19. Odendahl M, Keitzer R, Wahn U, et al. Perturbations of peripheral B lymphocyte homoeostasis in children with systemic lupus erythematosus. Ann Rheum Dis. 2003;62:851-8.

20. Jaimes MC, Rojas OL, Kunkel EJ, et al. Maturation and trafficking markers on rotavirus-specific B cells during acute infection and convalescence in children. $J$ Virol. 2004;78:10967-76.

21. Mei HE, Yoshida T, Sime W, et al. Blood-borne human plasma cells in steady state are derived from mucosal immune responses. Blood. 2009;113:2461-9.

22. Harada Y, Kawano MM, Huang N, et al. Identification of early plasma cells in peripheral blood and their clinical significance. Br J Haematol. 1996;92:184-91.

23. Hosomi S, Oshitani N, Kamata N, et al. Increased numbers of immature plasma cells in peripheral blood specifically overexpress chemokine receptor CXCR3 and CXCR4 in patients with ulcerative colitis. Clin Exp Immunol. 2010;163:215-24.

24. Turner D, Otley AR, Mack D, et al. Development, validation, and evaluation of a pediatric ulcerative colitis activity index: a prospective multicenter study.

Gastroenterology. 2007;133:423-32. 
25. Souza HS, Elia CC, Spencer J, et al. Expression of lymphocyte-endothelial receptor-ligand pairs, alpha4beta7/MAdCAM-1 and OX40/OX40 ligand in the colon and jejunum of patients with inflammatory bowel disease. Gut. 1999;45:856-63.

26. Ogawa H, Iimura M, Eckmann L, et al. Regulated production of the chemokine CCL28 in human colon epithelium. Am J Physiol Gastrointest Liver Physiol. 2004;287:G1062-9.

27. Schurmann GM, Bishop AE, Facer P, et al. Increased expression of cell adhesion molecule P-selectin in active inflammatory bowel disease. Gut. 1995;36:411-8.

28. Papadakis KA, Prehn J, Nelson V, et al. The role of thymus-expressed chemokine and its receptor CCR9 on lymphocytes in the regional specialization of the mucosal immune system. J Immunol. 2000;165:5069-76.

29. Kantele A, Savilahti E, Tiimonen H, et al. Cutaneous lymphocyte antigen expression on human effector B cells depends on the site and on the nature of antigen encounter. Eur J Immunol. 2003;33:3275-83.

30. Mackay CR, Marston WL, Dudler L, et al. Tissue-specific migration pathways by phenotypically distinct subpopulations of memory T cells. Eur J Immunol. 1992;22:887-95.

31. Abitorabi MA, Mackay CR, Jerome EH, et al. Differential expression of homing molecules on recirculating lymphocytes from sheep gut, peripheral, and lung lymph. J Immunol. 1996;156:3111-7.

32. Kansas GS. Selectins and their ligands: current concepts and controversies. Blood. 1996;88:3259-87.

33. Kunkel EJ, Campbell DJ, Butcher EC. Chemokines in lymphocyte trafficking and intestinal immunity. Microcirculation. 2003;10:313-23.

34. Dotson JL, Hyams JS, Markowitz J, et al. Extraintestinal manifestations of pediatric inflammatory bowel disease and their relation to disease type and severity. J Pediatr Gastroenterol Nutr. 2010;51:140-5.

35. Jose FA, Garnett EA, Vittinghoff E, et al. Development of extraintestinal manifestations in pediatric patients with inflammatory bowel disease. Inflamm Bowel Dis. 2009;15:63-8. 
36. Yacyshyn BR, Lazarovits A, Tsai V, et al. Crohn's disease, ulcerative colitis, and normal intestinal lymphocytes express integrins in dissimilar patterns.

Gastroenterology. 1994;107:1364-71. 